\title{
DO DNA EXTRACTION METHODS AND TAQ POLIMERASE QUALITY IMPROVE THE DOUBLE REPETITIVE ELEMENT (DRE) PCR TYPING METHOD FOR MYCOBACTERIUM TUBERCULOSIS STRAINS?
}

\author{
Hebe Rodrigues Cavalcanti ${ }^{1}$; Elizabeth Marques $^{1}$; Leila de Souza Fonseca ${ }^{2}$; Maria Helena Féres Saad ${ }^{3}$ \\ ${ }^{1}$ Hospital Universitário Pedro Ernesto, Universidade Estadual do Rio de Janeiro, Rio de Janeiro, RJ, Brasil; ${ }^{2}$ Instituto de \\ Microbiologia, Universidade Estadual do Rio de Janeiro, Rio de Janeiro, RJ, Brasil; ${ }^{3}$ Departamento de Micobacterioses, \\ Instituto Oswaldo Cruz, Fundação Instituto Oswaldo Cruz, Rio de Janeiro, RJ, Brasil
}

Submitted: May 15, 2006; Returned to authors for corrections: July 17, 2006; Approved: January 12, 2007

\begin{abstract}
Double repetitive element (DRE) PCR amplification is a simple Mycobacterium tuberculosis typing method, however amplification failure or poor resolution of bands commit its efficacy. In order to verify if whether or not these features could be minimized by improving DNA extraction procedures or Taq polymerise quality, DRE-PCR was performed on $24 \mathrm{M}$. tuberculosis DNA samples extracted by heat-shock, mechanical and enzymatic methods applying conventional and hot start Taq pol. We demonstrated that when dealing with the Mycobacterium tuberculosis DRE-PCR typing method, Taq pol of better quality might be more important to improve amplification than the DNA extraction method.
\end{abstract}

Key words: Mycobacterium tuberculosis, PCR, Taq hot start, DRE-PCR

Tuberculosis (TB) is a serious public health problem in developing countries, such as Brazil, where the disease is not properly controlled. Understanding the epidemiology of TB transmission in epidemic areas is important in effective and feasible TB control design (10). Molecular methods for Mycobacterium tuberculosis strain differentiation are important tools for epidemiological studies $(13,14)$. Although restriction fragment length polymorphism analysis based on the IS6110 insertion sequence is the gold standard among DNA fingerprinting methods (13), at the practical level it has some limitations such as time/labor investment, and requirement of specialized software and equipment, making this technique too expensive for implementation in developing countries (5). Alternative procedures based on polymerase chain reaction (PCR) have been developed, the simplest being the doublerepetitive-element PCR (DRE-PCR) designed for the detection of IS6110 inter-regions and the polymorphic G-C sequence (PGRS) $(3,7)$. However, despite simplicity and cost-efficiency of the DRE-PCR, reproducibility of this method has been reported to be suboptimal due to amplification failure or poor resolution of bands $(3,7,12)$. The aim of this work is to evaluate whether this limitation is related to the DNA extraction procedure or to Taq polymerase quality.

Twenty-four $M$. tuberculosis clinical isolates were submitted to the three different nucleic acid extraction procedures. All cellular DNA preparations were carried out with fresh M. tuberculosis cultivated at $37^{\circ} \mathrm{C}$ in Löewenstein-Jensen (LJ). The extraction procedures were: i) Heat shock - a full loop of cells reaching the $5 \mathrm{~mm}$ mark in a $1.5 \mathrm{~mL}$ microcentrifuge tube was boiled for $30 \mathrm{~min}$ in TE buffer and then frozen at $-20^{\circ} \mathrm{C}$ until application (3), ii) Mechanical - the same cell quantity was mixed with siliconized mini-glass beads, chloroform and TE buffer, in a Mickle cell disruptor (The Mickle Lab. Engeneering Co. Ltda, Gomshall, Surrey, UK) as described previously (9) and iii) Enzymatic - DNA was prepared with cetyl-trimethyl-ammonium bromide as described by Van Embden et al. (13). Amplification of each extracted DNA was performed by the DRE-PCR method, as described previously $(3,7)$, with minor modifications. Briefly, reaction mixtures containing $1.25 \mathrm{U}$ and 1.0 U of Taq polymerise and hot start Taq polymerase

*Corresponding Author. Mailing address: Departamento de Micobacterioses - Instituto Oswaldo Cruz - FIOCRUZ - Av. Brasil 4365 cep $21045-900$ Rio de Janeiro, RJ - Brasil. Tel.: (21) 2598-4346 ou (21) 2270-9997. E-mail: saad@ioc.fiocruz.br 
(Invitrogen do Brasil Ltda), respectively, were prepared. Each mixture was added to a $10 \mu \mathrm{l}$ batch of DNA obtained by heatshock and to a $1 \mu \mathrm{l}$ batch of mechanically or enzymatically extracted DNA to a final volume of $50 \mu \mathrm{l}$ each. The cycling parameters included an initial denaturation at $95^{\circ} \mathrm{C} / 10 \mathrm{~min}$. and 30 cycles of $94^{\circ} \mathrm{C} / 1 \mathrm{~min}, 56^{\circ} \mathrm{C} / 2 \mathrm{~min}$ and a final extension of $72^{\circ} \mathrm{C} / 10 \mathrm{~min}$. The amplified products $(20 \mu \mathrm{l})$ were eletrophoresed on $1.8 \%$ agarose-gels (Sigma, Saint Louis, CA, USA). Each amplification procedure was performed two times in different days. The amplification efficiency was calculated as, $\mathrm{EC}=\Sigma(\mathrm{n}$ . $y) / x$, where $n=$ number of amplified fragments, $y=$ number of strains that amplified the same number of fragments and $x=$ total numbers of the strains.

The results obtained, with each DNA extraction method vs. each Taq polymerise, were analyzed visually. Improvement in band resolution was analyzed comparing the results for each Taq polymerize master mix (Fig. 1). Results in number of amplified samples with Taq polymerase hot start were significantly higher then results elicited by conventional Taq polymerize ( $\mathrm{p}<0.003$, Wilcoxon's Test), regardless the DNA extraction method (Fig.

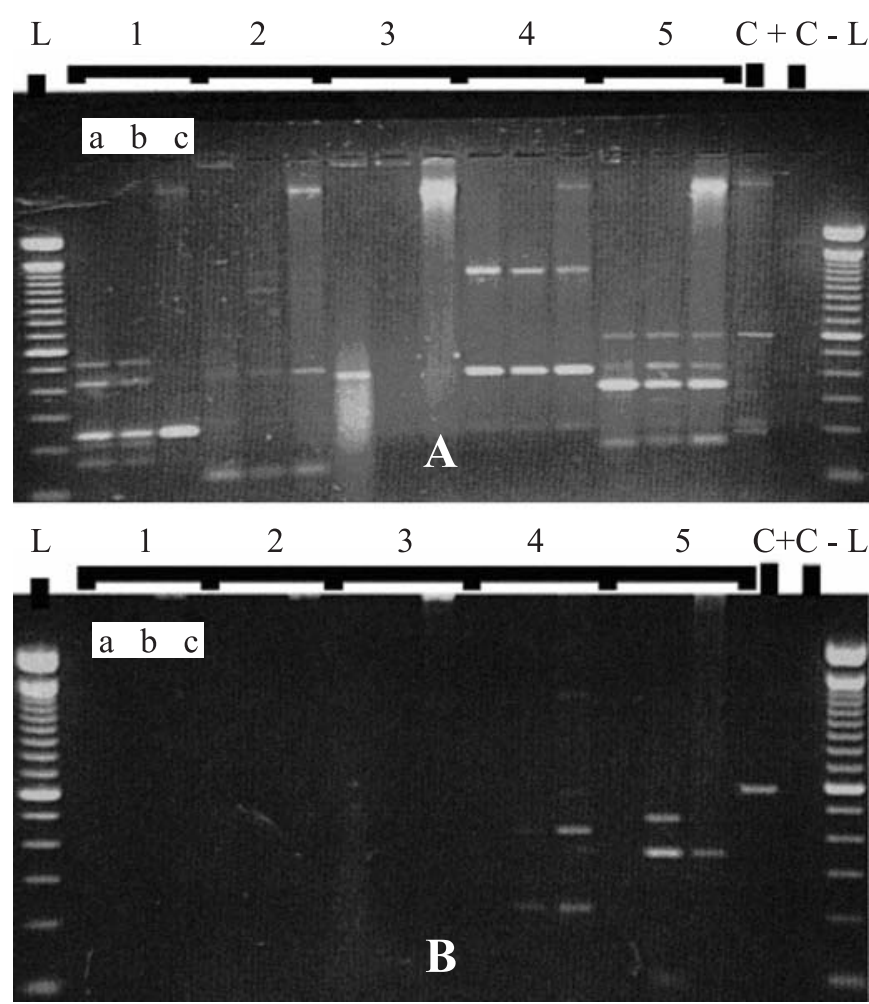

Figure 1. DRE-PCR patterns using DNA extracted by HeatShock (a), Mechanical (beads-Mickle - b) and Enzymatic (c) methods, and PCR reaction mixture containing (A) hot start Taq polymerase and (B) Taq polymerase.

L- Ladder 100bp, numbers- ID patients, C+: Positive control, C: Negative control.
2). Despite seeming superior than the other DNA extraction methods, the mechanical extraction method resulted in a number of bands that did not differ significantly ( $\mathrm{p}=0.826$, Friedman's test) for a same collection of isolates. Each amplification procedure was repeated two times without significant difference in band patterns.

Variations in DNA preparation, such as purity, size, concentration and presence of inhibitors, have been known to interfere with PCR amplification (7). In our study, size and purity were not disturbance factors, which is not surprising since the targeted insertion sequences were present in multiple copies, improving primer binding, even in disrupted DNA obtained by heat-shock or mechanical extraction methods. Concentration is also well known to be a problem. The enzimatically extracted DNA was amplified only after dilution, even when hot start Taq polymerase was used (data not shown). The amplification failure may have been due to inhibition by phenol residues associated with the enzymatic method, as described by Sola et al. (11). These authors reported that mechanical extraction led to a lower number of amplified fragments of DNA. However, our results did not exhibit significant differences among DNA extraction methods when hot-start $T a q$ polymerase was employed, although the enzymatic extraction was slightly less efficient than the mechanical method.

During PCR set-up, two types of undesirable DNA amplifications may impair the yield and/or specificity of the test: mispriming and/or formation of a dimmer primer. These

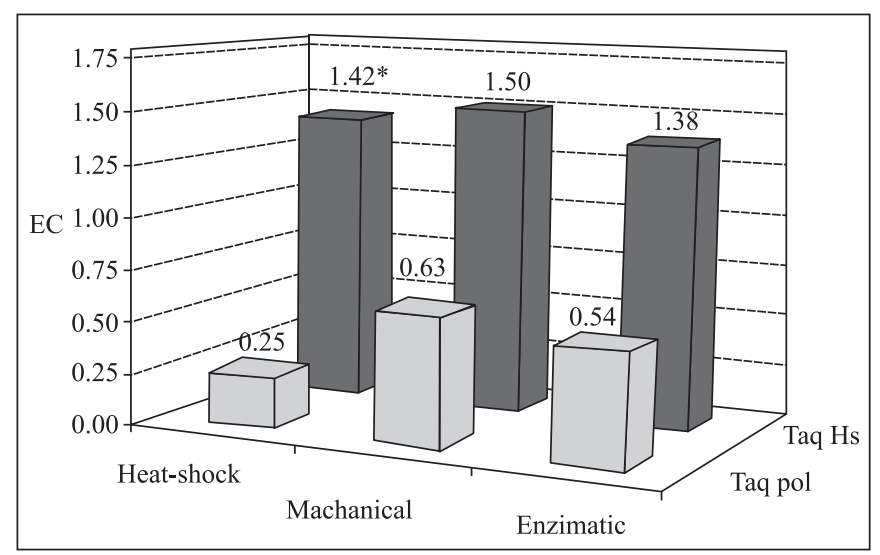

Figure 2. Efficiency of DRE-PCR amplification DNA, extracted by Heat-Shock, Mechanical (Beads-Mickle) and Enzymatic methods. Efficiency was express by the number of bands divided by the number of strains assayed with reaction mixture containing $T a q$ polymerase (Taq pol) and hot start Taq polymerase ( $\mathrm{Taq} \mathrm{Hs}$ ) using the following formula: $\mathrm{EC}=\Sigma(\mathrm{n} \mathrm{x} \mathrm{y}) /$ $\mathrm{x}$, where $\mathrm{n}=$ number of amplified fragments, $\mathrm{y}=$ number of strains that amplified the same number of fragments and $\mathrm{x}=$ total number of the strains tested. 
events take place particularly in amplifications involving high cycle numbers, high G-C content of the template DNA or multiple primer pairs (6). M. tuberculosis DNA typing by DRE-PCR is included in last two conditions since these organisms have high G-C content (2) and DRE-PCR requires two pairs of primers. These characteristics may be responsible for the suboptimal test results. Hot-start Taq polymerase is protected by a heatresistant antibody, thus DNA synthesis before the reaction has been warmed to the normal DNA extension temperature is reduced or prevented. This favored primer accessibility and improved the amplification by avoiding primer stable annealing not only to each other but to unwanted template sequences as well, which may have contributed to a reduction in the yield of faint bands (6).

The effects of additives or co-solvents on PCR are not well understood. They seem to affect the melting temperature of the primer, the thermal activity profile of $T a q$ polymerase and the degree of product strand separation. Dimethyl sulfoxide, among other additives, has been reported to improve DRE-PCR amplification due to its strong activity on G-C rich DNA denaturation (8). However the final concentration must not exceed $10 \%$, as it can inhibit Taq polymerase activity by $50 \%$ (4). According to our study, the use of hot start Taq polymerase without addition of any other reagent seems to be enough for rapid strain typing. However, as the faint bands were not completely eliminated in some samples, hampering pattern interpretation when dealing with a great number of strains, DREPCR hot-start amplification may be indicated for special situations, such as for small outbreaks tracing, and tracking of laboratory cross contamination and policlonal infection $(1,7)$, been useful in developing countries for easy and rapid strain typing.

\section{AKNOWLEDGEMENTS}

This study was financed by FAPERJ, CNPq (Milênio), Rio de Janeiro, Brazil. Reviewed and revised by Mitchell Raymond Lishon, Native of Chicago, Il, USA - UCLA 69.

\section{RESUMO}

\section{Os métodos de extração de DNA e a qualidade DA Taq polimerase podem melhorar a tipagem molecular de M. tuberculosis por DRE-PCR}

Amplificação de duplo elemento repetido (DRE) por PCR é um método simples para tipagem de Mycobacterium tuberculosis, entretanto falha ou a baixa resolução das bandas na amplificação compromete a eficiência do método. Com o objetivo de verificar se estes problemas podem ou não ser minimizados pela utilização de diferentes procedimentos de extração de DNA ou de qualidades de Taq polimerase, DRE-
PCR foi ensaiado em 24 amostras de DNA de M. tuberculosis extraídos pelos métodos de choque-térmico, - mecânico e enzimático utilizando Taq polimerase convencional e hot start Taq pol. Foi demonstrado que a qualidade da Taq pol utilizada talvez seja mais importante para uma melhor amplificação que o método de extração de DNA empregado.

Palavras-chave: Mycobacterium tuberculosis; PCR; Taq hot start; DRE-PCR

\section{REFERENCES}

1. Anjos Filho, L.; Kritski, A.L.; Salles, C.L.G.; Sardella, I.G.; Silva, M.G.; Fonseca, L.S. \& Saad, M.H.F. (2002). Mycobacterium tuberculosis typing: usefulness of DRE-PCR to confirm crosscontamination in the mycobacteriology laboratory of a general reference hospital for AIDS. Int. J. Tuber. Lung Dis., 6(2): 1-5.

2. Cole, St.; Brosh, R.; Parkhill,J.; Garnier,T.; Churcher, C.; Harris, D.; Gordon, S.V.; Eiglmeier, K.; Gas, S.; Barry, C.E.; Tekaia, F.; Badcock, K.; Basham, D.; Brown, D.; Chillingworth, T.; Connor, R.; Davies, R.; Devlin, K.; Fetwell, T.; Gentles, S.; Hamlin, N.; Holroyd, S.; Hornsby, T.; Jagels, K.; Krogh, A.; Mclean, J.; Moule, S.; Murphy, L.; Oliver, K.; Osborne, J.; Quail, M.A.; Rajandream, M.A.; Rogers, J.; Rutter, S.; Seeger, K.; Skelton, J.; Squares, R.; Sulston, J.E.; Taylor, K.; Whitehead, S.; Barrel, B.G. (1998).Deciphering the biology of Mycobacterium tuberculosis from the complete genome sequence. Nature, 393: 537-544.

3. Friedman, C.R.; Stoeckle, M.Y.; Johnson, W.D. \& Riley, L.W. (1995). Double-Repetitive-Element PCR method for subtyping Mycobacterium tuberculosis clinical isolates. J. Clin. Microbiol. 33(5): 1383-1384.

4. Gelfand D.H.; White T.J. (1990). Thermostable DNA polymerases. In: Innis MA, Gelfand DH, Sninsky JJ, White TJ (Eds). PCR Protocols: A guide to methods and applications. Academic Press, Inc., San Diego, USA, p.129-141.

5. Kanduma, E.; Mc Hugh, T.D.; Gillespie, S.H. (2003). Molecular methods for Mycobacterium tuberculosis strain typing: users guide J. Applied Microbiol., 84(5): 781-791.

6. Kermekchiev MB, Tzekov A, Barnes WM. (2003). Cold-sensitive mutants of Taq DNA polymerase provide a hot start for PCR. Nucleic Acids Res., 31(21): 6139-6147.

7. Kremer, K.; Van Soolingen, D.; Frothingham, R.; Haas, W.H.; Hermans, P.W.M.; Martin, C.; Palittapongarnpim, P.; Plikaytis, B.B.; Riley, L.W.; Yakrus, M.A.; Musser, J.M.; Van Embden, J.D.A. (1999) Comparison of methods based on different molecular epidemiological markers for typing of Mycobacterium tuberculosis complex strains: Interlaboratory study of discriminatory power and reproducibility. J. Clin. Microbiol., 37(8): 607-618.

8. Montoro, E.; Valdivia, J. \& Cardoso Leão, S. (1998). Molecular fingerprinting of Mycobacterium tuberculosis isolates obtained in Havana, Cuba, by IS 6110 restriction fragment length polymorphism analysis and by the double-repetitive-element PCR method. J. Clin. Microbiol., 36(10): 3099-3102.

9. Plikaytis BB, Gelber RH, Shinnick TM. (1990). Rapid and sensitive detection of Mycobacterium leprae using a nested-primer gene amplification assay. J. Clin. Microbiol., 28(9): 1913-1917.

10. Raviglione, M.C. (2003). The TB epidemic from 1992 to 2002. Tuberculosis, 83(3): 4-14.

11. Sola, C.; Horgen, L.; Maïsetti, J.; Devallois, A.; Goh, K.S. \& Rastogi, N. (1998). Spoligotyping followed by Double-Repetitive- Element PCR as rapid alternative to IS6110 fingerprinting for epidemiological studies of tuberculosis. J. Clin. Microbiol., 36(4): 122-1124. 
12- Spurgiesz, R.S.; Quitugua, T.N.; Smith, K.L.; Schupp, J.; Palmer, E.G.; Cox, R.A.; Keim, P. (2003). Molecular typing of Mycobacterium tuberculosis by using nine novel variable-number tandem repeats across the Beijing Family and low-copy-number IS 6110 isolates. $J$. Clin. Microbiol., 41(9): 4224-4230.

13. Van Embden, J.D.A.; Cave, M.D.; Crawford, J.T.; Dale, J.W.; Eisenach, K.D.; Gicquel, B.; Hermans, P.; Martin, C.; Mc Adam, R.;
Shinnick, T.M. \& Small, P.M. (1993). Strain identification of Mycobacterium tuberculosis by DNA fingerprinting: recommendation for a standardized methodology. J. Clin. Microbiol., 31(12): 406-409.

14. Van Soolingen, D. (2001). Molecular epidemiology of tuberculosis and other mycobacterial infections: main methodologies and achievements. J. Intern. Med., 249(1): 1-26. 